Proceedings

\title{
Energy Valorisation of Wastewater Treatment Plant Sludge through Thermal Gasification: An Economic Perspective ${ }^{+}$
}

\author{
Luis F. Carmo-Calado*, Roberta Mota-Panizio, Gonçalo Lourinho, Octávio Alves, I. Gato \\ and Paulo Sérgio Duque de Brito
}

VALORIZA-Research Center for Endogenous Resource Valorisation, Polytechnic Institute of Portalegre, 7300-555 Portalegre, Portugal; rpanizio@ipportalegre.pt (R.M.-P.); goncalo.lourinho@ipportalegre.pt (G.L.); octavio.alves@ipportalegre.pt (O.A.); ilda.gato@ipportalegre.pt (I.G.); pbrito@ipportalegre.pt (P.S.D.d.B.)

* Correspondence: luis.calado@ipportalegre.pt

+ Presented at the Bioenergy International Conference, Portalegre, Portugal, 11-13 September 2019.

Published: 6 April 2021

\begin{abstract}
The technical-economic analysis was carried out for the production of sludge-derived fuel from a municipal wastewater treatment plant (WWTP). The baseline for the analysis consists of a sludge drying plant, processing $6 \mathrm{~m}^{3}$ of sludge per day and producing a total of about $1 \mathrm{~m}^{3}$ of combustible material with $8 \%$ of moisture and a higher calorific power of $18.702 \mathrm{MJ} / \mathrm{kg}$. The transformation of biofuel into energy translates into an electricity production of about $108 \mathrm{~kW}$ per $100 \mathrm{~kg}$ of sludge. The project in the baseline scenario demonstrated feasibility with a payback time of about six years.
\end{abstract}

Keywords: sludge; gasification; drying and economic evaluation

\section{Introduction}

Enormous amounts of sludge with high organic content are produced at different stages of the wastewater treatment plant (WWTP) treatment. The sludge production rate varies according to the country and region, and is directly related to the characteristics of wastewater and the processes applied in the treatment [1]. By 2020, Europe is expected to be responsible for generating 12 million tons per year, with an estimated sludge production rate being around 0.1 to $30.8 \mathrm{~kg}$ per population equivalent per year $(\mathrm{kg} / \mathrm{PE} /$ year $)$ [2].

In Portugal, in 2016, 700,000 tons of these "wastes" were generated, where this fraction is sent to landfill and represents a significant quantitative value, ranging between $50 \%$ and $60 \%$ of the material processed in the installation [3].

Several technologies are being developed to convert sewage sludge into usable energy, with anaerobic digestion and incineration dominating the practical application of these processes [4]. The thermochemical conversion of the sludges into energy and fuel, has been widely studied and has been considered as one of the most attractive technologies to deal with cumulative amounts of production due to the increased number of WWTPs. The thermochemical process not only offers a massive reduction in volume, but also becomes effective in destroying pathogens agents [5].

The present study demonstrate a process model and technical-economic analysis for the production of centrifugal sludge-derived fuel from a municipal wastewater treatment plant (WWTP) and subsequent biofuel improvement and subsequent energy recovery. 


\section{Recovery Process}

The sludge recovery process took place in a chair process, where it entered through a rotary dryer to remove a large percentage of the moisture, after, the dried sludge is sent to a pelletizing system which, after being turned into pellets, is ready for energy recovery by thermal gasification. This study aims to demonstrate the economic viability for drying and subsequent energy recovery of WWTP sludge from a population of about 15,000 habitants, with a monthly production of 180 tons of sludge, which amounts to about $0.4 \mathrm{~kg} / \mathrm{hab}$ per day. This required a qualitative characterization of the sludge produced (mass, volume, thermogravimetric and elemental analysis), as well as technical and economic evaluation of the drying system and the recovery system (gasification).

From the above, several tests were performed to characterize the collected sludge, whose characteristics are represented in the following Table 1.

Table 1. Characterization of the sludge from the wastewater treatment plant.

\begin{tabular}{ccc}
\hline Properties & Parameters & Values \\
\hline Apparent density $\left(\mathrm{kg} / \mathrm{m}^{3}\right)$ & 1048 \\
\hline & Moisture $(\mathrm{wt} \% \mathrm{ar}){ }^{1}$ & 86.7 \\
Volatile matter $(\mathrm{wt} \% \mathrm{db})^{2}$ & 69.1 \\
Altimate analysis & 23 \\
& Ashes $(\mathrm{wt} \% \mathrm{db})$ & 23 \\
Fixed carbon $(\mathrm{wt} \% \mathrm{db})$ & 7.9 \\
\hline Chlorine content $(\mathrm{wt} \% \mathrm{db})$ & 0.1 \\
Higher Heating Value (HHV) $(\mathrm{MJ} / \mathrm{kg} \mathrm{db})$ & 18.7 \\
\hline${ }^{1}$ Weight percent, as received basis. ${ }^{2}$ Weight percent, dry basis.
\end{tabular}

Based on the process, the mass balance was defined, accounting for all the inputs and outputs that involves the process. After the sludge storage process, where there is a preheat to remove $6 \%$ moisture (from $86 \%$ to $80 \%$ ), the sludge goes through a chain aiming at the optimization (drying and pelletizing) of raw material that will later enter in the gasifier. Said chain is composed of a rotary dryer $\left(3 \mathrm{~m}^{3} / \mathrm{h}\right)$ that reduces the sludge humidity up to about $26 \%$, followed by a pelletizing system $(100 \mathrm{~kg} / \mathrm{h})$, where the sludge finally attains a humidity of $8 \%$.

The sludge pellets are gasified in an updraft fluidized bed thermal gasification reactor $(100 \mathrm{~kg} / \mathrm{h})$ where it becomes a combustible gas called syngas. After cleaning in a filter and a condenser system, this syngas will be burned in an internal combustion engine for power generation. In this type of gasifier, the fuel is processed at temperatures between $700{ }^{\circ} \mathrm{C}$ and $900{ }^{\circ} \mathrm{C}$. Fluidization of the bed is achieved by introducing air from the bottom of the reactor and a layer of sand into the reactor, usually dolomite, to keep the biomass in suspension. The most important features of this type of gasification are: flexibility for changes in fuel properties, sizes and shapes; moisture up to $60 \%$; and higher ash content.

\section{Results and Discussion}

The unit will be designed for the power to be injected at the receiving point be $150 \mathrm{~kW}$, considering a power factor of 0.93 . The values used in the calculations are shown in Table 2.

Table 2. Important data for the feasibility calculations of the installation project.

\begin{tabular}{cc}
\hline \multicolumn{2}{c}{ Total Power to Install } \\
\hline Gross Power (generator terminal power) & $110 \mathrm{~kW}$ \\
Elevator Transformer Yield & $99.20 \%$ \\
Line Losses & $1.80 \%$ \\
Receiving Point & \\
Maximum power to be injected at the receiving point & $0.110 \mathrm{MW}$ \\
Power Factor & 0.93 \\
\hline
\end{tabular}


The project inputs include the dryer and oven, pelletizer, and gasifier, with $65.38,126.5$ and 270 $\mathrm{kWh}$, respectively. The output involved in the process is related to the motor, with a production of $1,296,288 \mathrm{kWh}$.

\subsection{Consumption and Production Indicators}

The sum of all unit consumptions per day are shown below in Table 3.

Table 3. Consumptions per day of all units of the system.

\begin{tabular}{ccccc}
\hline Unit & Dryer & Pelletizer & Gasifier & Total \\
\hline Electric Energy $(\mathrm{kWh} /$ day) & 65.38 & 126.5 & 270 & 461.88 \\
\hline
\end{tabular}

Regarding the indicators for the electricity produced, the gasification unit, as mentioned above, has a consumption capacity of $100 \mathrm{~kg} / \mathrm{h}$ of sludge and $90 \mathrm{~m}^{3} / \mathrm{h}$ of air, which corresponds to about 90 $\mathrm{m}^{3} / \mathrm{h}$ of syngas produced. During experiments carried out at the Portalegre Polytechnic Institute, an average of $5 \mathrm{MJ} / \mathrm{m}^{3}$ of lower calorific value syngas produced was obtained.

Knowing the efficiency of the internal combustion engine (30\%) and the power generator $(80 \%)$, we can use Formula (1).

$$
\text { Pe }=\text { Qsyngás . LHVsyngas . } \eta E n g i n e ~ . \eta G e n e r a t o r ; P e=90.02 \quad .5 \quad 0.3 \quad 0.8 ; P e=108,024 \mathrm{~kW}
$$

As planned in the project, the gasification unit will work for $12 \mathrm{~h}$ a day, 330 days a year, which translates into a total energy of $427.78 \mathrm{MWh} /$ year.

\subsection{Economic Feasibility Analysis}

The added value will be energy and sludge reception (treatment). Actually, the cost for sludge final destination is approximately $35 € /$ ton, produced and dehydrated, so the energy recovery and drying unit would be left with dehydrated sludge for a total cost of $€ 30$, which would save about $14.3 \%$ of total cost currently charged.

\subsubsection{Energy}

The total annual production, which corresponds to $12 \mathrm{~h}$ per day, 27.5 days per month and 330 days per year, corresponds to a total of $427.78 \mathrm{MWh}$ per year. Formula (2) was used in the calculation.

$$
P e=E d a y \quad .330 ; P e=1296,288.330 ; P e=427,75 \text { MWh/year }
$$

As the unit foresees self-consumption, it has to account for the electricity consumed annually, which corresponds approximately to $152.42 \mathrm{MWh} /$ year. For this calculation, Formula (3) was used.

$$
\text { Econsumed }=\text { Eday } .330
$$

The difference between the produced energy and the consumed energy results in the sale of energy to the electricity grid at a total of $275.36 \mathrm{MWh} /$ year which, after losses in the line $(1.8 \%)$, corresponds to a total of $270.4 \mathrm{MWh} /$ year, with a sale price of about $0.2 €[6]$. With respect to economic indicators, the project has a net present value (NPV) of $€ 134.619$, an internal rate pf return (IRR) of $12.55 \%$ and a payback period of approximately six years. As the project is quite viable, no external funding is required for its implementation.

\subsubsection{Justification of Equipment Costs}

The costs involved for the acquisition/maintenance of the equipment are presented in Table 4.

Table 4. Costs involved in the acquisition and maintenance of the sludge energy recovery unit.

\begin{tabular}{cccccc}
\hline Unit & Rotary Dryer & Pelletizer & Gasifier & Operation & Investment \\
\hline Price $(€)$ & 150,000 & 5000 & $140,431.2$ & 21600 & $295,431.2$ \\
Maintenance/year $(€)$ & 7500 & 250 & 7021.56 & & $36,371.56$ \\
\hline
\end{tabular}


Table 5 gives a summary of the parameters considered in the economic evaluation and the results calculated for annual cash flows, NPV and payback period (PP) for the unit proposed.

Table 5. Parameters for economic analysis and corresponding results for the construction of a gasification plant.

\begin{tabular}{cccc}
\hline System Parameters & \multicolumn{3}{c}{ Economic Evaluation Results } \\
\hline Type of gasifier & Bubbling fluidized bed & Profits (annual, k€) & 70.947 \\
Thermal power $(\mathrm{MW})$ & Own consumption & Electric energy $(\mathrm{k} €$ ) & 54.08 \\
Electrical power $(\mathrm{MW})$ & 0.108 & Sludge $(\mathrm{k} €$ ) (3\% inflation rate year) & 59.4 \\
Feedstock & WWTP Sludge & Costs (annual, k€) & 11.348 \\
Quantity (ton/year) & 363 & Operating cost $(\mathrm{k} €)$ & 31.185 \\
Biomass HHV (MJ/kg) & 18 & Economic evaluation results & 77.3 \\
Economic parameters & & Annual cash flow (k€) & 12.55 \\
Investment $(€ / \mathrm{kW})$ & 1300 & IRR $(\%)$ & 134.619 \\
Price of electricity (€/kWh) & 0.086 & NPV $(\mathrm{M} €)$ & 6 \\
Operative costs (\% investment) & 12.311 & PP (years) & \\
Lifetime (years) & 15 & & \\
\hline
\end{tabular}

\section{Conclusions}

The present study aimed to test the use of thermal gasification process as a way to valorize waste residues into a useful gas for energy production purposes, as well as to evaluate the economic feasibility of the construction of a plant able to process residues produced in a municipality waste water treatment plant. The justification for the investment is related to the current costs of landfill sludge deposition, 78,120 €/year, as well as the environmental policy governing of this co-product. Based on the economic assessment, the entity would save about 10,936 €/year (14.3\%) and have an energy profit of $70,947 € /$ year.

Centered on the study and on the presented results, the feasibility of transforming sludge, high polluting waste into valuable, hydrogen-rich gas and other products that are highly relevant in terms of heating power and are of interest to the chemical industry was demonstrated.

\section{References}

1. Udayanga, W.D.C.; Veksha, A.; Giannis, A.; Lisak, G.; Chang, V.W.C.; Lim,T.T. Fate and distribution of heavy metals during thermal processing of sewage sludge. Fuel 2018, 226, 721-744.

2. Syed-Hassan, S.S.A.; Wang, Y.; Hu, S.; Su, S.; Xiang, J. Thermochemical processing of sewage sludge to energy and fuel: Fundamentals, challenges and considerations. Renew. Sustain. Energy Rev. 2017, 80, 888913.

3. Pordata "Produção de resíduos: Total e Por Tipo de Resíduo". Available online: https://www.pordata.pt/DB/Europa/Ambiente+de+Consulta/Tabela (accessed on 1 October 2019).

4. Metcalf, E.; Eddy, H. Wastewater engineering: Treatment and reuse. Am. Water Work. Assoc. J. 2003, 95, 201.

5. Chen, P.; Xie, Q.; Addy, M.; Zhou, W.; Liu, Y.; Wang, Y.; Cheng, Y.; Li, K.; Ruan, R. Utilization of municipal solid and liquid wastes for bioenergy and bioproducts production. Bioresour. Technol. 2016, 215, 163-172.

6. Republica Portuguesa, Portaria n. ${ }^{\circ} 15 / 2015$ de 23 de janeiro. Diário da República 2015, 1, 531-532. 